\title{
Identification of the Phytoplasma Associated with Wheat Blue Dwarf Disease in China
}

Yunfeng Wu, Northwest A\&F University - College of Plant Protection and Shaanxi Key Laboratory of Molecular Biology for Agriculture, Key Laboratory of Plant Protection Resources and Pest Management, Ministry of Education, Yangling, China; Xingan Hao, Northwest A\&F University, and Agriculture and Agri-Food Canada - Pacific Agri-Food Research Center, Summmerland, British Columbia, Canada; Zhengnan Li, Northwest A\&F University; Peiwen Gu, Ningxia University - Agricultural School, Yinchuan, China; Fengqui An, Jianye Xiang, and Haini Wang, Northwest A\&F University; Zhaopeng Luo, China National Tobacco Corporation - Zhengzhou Tobacco Research Institute, Zhengzhou, China; Junjun Liu, Natural Resources Canada - Pacific Forestry Centre, Victoria, British Columbia; and Yu Xiang, Agriculture and Agri-Food Canada - Pacific Agri-Food Research Center

\begin{abstract}
Wu, Y., Hao, X., Li, Z., Gu, P., An, F., Xiang, J., Wang, H., Luo, Z., Liu, J., and Xiang, Y. 2010. Identification of the phytoplasma associated with wheat blue dwarf disease in China. Plant Dis. 94:977-985.

Wheat blue dwarf disease (WBD) was first reported in China in the1960s. It has caused severe losses on several occasions in winter wheat (Triticum aestivum) in northwestern China, and the nature of the pathogenic agent has been unknown. Here we have shown that WBD was caused by a 16 SrI-C phytoplasma transmitted by Psammotettix striatus. This finding was based on molecular diagnostics, insect transmission trials, and host-range determination. Portions of the 16S rRNA and ribosomal protein (rp) genes, $r p s S$ ( $r p s 19), r p l V$ (rpl22), and rpsC (rps3), were amplified from DNA samples of WBD-infected wheat seedlings by polymerase chain reaction (PCR) utilizing phytoplasma specific primer pairs. The nucleotide sequences of these amplicons showed high identity to these genes from phytoplasma strains in the aster yellows group (16SrI). Pairwise nucleotide sequence identities of WBD 16S rDNA compared to representative genes of 16SrI group strains ranged from 98.9 to $99.9 \%$, whereas compared to 17 other phytoplasma groups (16SrII to $16 \mathrm{SrXVIII}$ ), sequence identity ranged from 88.6 to $96.0 \%$. Similarly, the sequence identities of rps 19, rpl22, and rps3 between WBD and 16SrI group strains varied from 96.6 to $99.7 \%$, but only 60.3 to $65 \%$ between WBD and other phytoplasma groups. Phylogenetic analyses were carried out on sequences from 16S rRNA and ribosomal protein genes (rps19, $r p l 22$, and rps3), respectively, and both results indicated that WBD phytoplasma was a member of the $16 \mathrm{SrI}$ group and most closely related to subgroup 16SrI-C. WBD-infected $P$. striatus were present in wheat fields with WBD, and phytoplasma infection was verified by PCR detection followed by DNA sequencing. Insect transmission trials confirmed that $P$. striatus transmitted the WBD phytoplasmal agent from infected wheat to healthy wheat seedlings and seven other different plant species in the greenhouse. A survey of various weed species near WBD-infected wheat fields found 10 plant species in seven families to be positive for the presence of WBD phytoplasma.
\end{abstract}

Wheat blue dwarf disease (WBD) is one of the most important crop diseases affecting winter wheat (Triticum aestivum L.) in arid and semiarid areas of northwestern China, including Shaanxi, Shanxi, Gansu, and Ningxia provinces. This disease was first reported in the 1960s and was named wheat red dwarf disease because it exhib-

Corresponding author: Yunfeng Wu

E-mail: wuyf@nwsuaf.edu.cn

Yunfeng Wu and Xingan Hao are co-first authors.

* The $\boldsymbol{e}$-Xtra logo stands for "electronic extra" and indicates that Figure 1 appears in color in the online edition.

Accepted for publication 7 April 2010.

doi:10.1094/PDIS-94-8-0977

(c) 2010 The American Phytopathological Society ited reddening and stunting symptoms in purple-stalked wheat varieties $(27,44)$. Later, it was renamed wheat blue dwarf disease to distinguish it from wheat yellow dwarf disease caused by Barley yellow dwarf virus (BYDV) and Cereal yellow dwarf virus (CYDV) in China (42-45). Typically, WBD-infected wheat plants were severely stunted and dwarfed, with numerous short tillers developing at the base of the plants. Infected center leaves showed chlorotic mottling and curling or failed to expand. Lower leaves and stems were dark blue-green and gradually became stiff and thickened. In severely infected wheat plants, spikes were either deformed and sterile, or they did not develop at all $(28,43)$. Epidemics of this disease have occurred more than 10 times in Shaanxi Province since 1960. Incidence of the disease was estimated to cover 900,000 ha and caused a total loss of about
50,000 metric tons of wheat yield during an average epidemic year (43).

WBD had been presumed to be a plant virus disease for many years. Subsequently, mycoplasma-like organisms (MLO) were observed in the phloem tissues of WBD-infected wheat $(2,43)$, and in the saliva tissue of its leafhopper vector Psammotettix striatus under electron microscopy $(39,43)$. P. striatus was the only leafhopper species that was identified and confirmed to transmit WBD in the field (43,44). WBD-infected $P$. striatus can persistently transmit the disease for the rest of its life, but it does not have transovarial transmission $(39,43)$. Despite the progress of research on this disease, it had still not been confirmed that a phytoplasma was the cause of WBD.

Phytoplasmas are wall-less bacteria that are transmitted by phloem-feeding insects in nature, mainly leafhoppers and psyllids. They can inhabit and propagate in both plant phloem tissues and their insect vectors $(16,20,33)$. Phytoplasmas cause complex disease syndromes with symptoms such as stunting, proliferation of auxiliary shoots, formation of sterile-deformed flowers, virescence, and phyllody in several hundred plant species (16). Since phytoplasmas cannot be cultured under axenic conditions, their identities and taxonomic positions were uncertain until recently, when molecular techniques were applied to the study of phytoplasmas. Cloned phytoplasma DNA probes, restriction fragment length polymorphism (RFLP), and sequences of genes, such as the 16S rRNA, ribosomal protein (9), and elongation factor TU (tuf) genes, are now widely used to differentiate various groups and subgroups of phytoplasmas $(11,20,26,30,31,38)$. Most of the phytoplasmas that infect economically important crops have been classified phylogenetically using these techniques. Based on phylogenetic analysis of several gene sequences (16S rRNA, rps/rpl, and tuf), phytoplasmas were recently assigned to a provisional genus, "Candidatus $(\mathrm{Ca}$.) Phytoplasma" within the class Mollicutes, which included 26 named species (9). More recently, Wei et al. (38) classified 
phytoplasmas into 28 phylogenic groups and 50 subgroups according to computersimulated RFLP analysis of 16S rRNA gene sequences.

Although WBD has been present in China since the early1960s, most research on WBD focused on symptom descriptions, vector transmission tests, and electron microscopy. The objectives of the present study were to identify the causal agent of WBD and reinvestigate its vector transmission and host range using molecular diagnostic techniques. Our investigation revealed that WBD is caused by a new phytoplasma belonging to the 16SrI-C phytoplasma group with a unique leafhopper vector and a special crop host range.

\section{MATERIALS AND METHODS}

Plants, insects, and source of disease vum cv. Xiaoyan 6) was used in this study. Wheat seedlings with or without WBD symptoms were collected from fields in Hancheng, Shaanxi Province, China and transplanted into pots in an insect-proof greenhouse. Leafhoppers (Psammotettix striatus and Tettigella viridis) and aphids (Aphis gossypii, Macrosiphum avenae, Myzus persicae, Rhopalosiphum padi, $R$. maidis, and Schizaphis graminum) that were frequently found in wheat fields during the spring wheat-growing season were collected from the fields. P. striatus, $T$. viridis, R. padi, M. avenae, and S. graminum were reared on healthy wheat seedlings, $R$. maidis on maize (cv. Cazorla), $M$. materials. Winter wheat (Triticum aesti-

persicae on Brassica rapa, and A. gossypii on watermelon. All insect species were maintained in growth chambers at $23^{\circ} \mathrm{C}$ (day) and $18^{\circ} \mathrm{C}$ (night) with a photoperiod of $14 \mathrm{~h}$ of light and $10 \mathrm{~h}$ of dark. The only exception was for P. striatus and S. graminum, which were cultured at a constant temperature of $14^{\circ} \mathrm{C}$ and a photoperiod of $14 \mathrm{~h}$ of light and $10 \mathrm{~h}$ of dark. Paulownia witches'-broom phytoplasma (PaWB), which is a representative strain of " $\mathrm{Ca}$. Phytoplasma asteris" 16SrI-D (32), and chinaberry witches'-broom phytoplasma (CWB), an identified strain in the 16SrI-B subgroup (21), were used as a phytoplasma reference strains in this study.

Insect transmission. All insect species collected from the diseased fields were allowed to feed directly on healthy wheat seedlings (5 insects/seedling and 15 seedlings/trial) for 1 week to test for transmission of the disease. Pathogen-free, laboratory colonies of $P$. striatus and $T$. viridis were obtained originally from egg-hatched offspring on healthy wheat plants and were transferred on healthy wheat seedlings for several generations. Pathogen-free, as well as laboratory colonies, of all six aphid species were initiated from single viviparous aptera collected from healthy hosts. These hosts were wheat for $R$. padi, $S$. graminum, and $M$. avenae, maize for $R$. maidis, Brassica rapa for $M$. persicae, and watermelon for A. gossypii. For transmission trials, healthy insect larvae were fed for 2 or 3 days on WBD-symptomatic wheat plants for acquisition of the causal

Table 1. Occurrence of symptoms and phytoplasma infection in plant species inoculated by wheat blue dwarf disease (WBD)-infected Psammotettix striatus leafhoppers

\begin{tabular}{|c|c|c|c|}
\hline Species tested & $\begin{array}{c}\text { No. of } \\
\text { symptomatic } \\
\text { plants }^{\mathrm{a}}\end{array}$ & $\begin{array}{c}\text { Detection of } \\
\text { phytoplasmas } \\
\text { by PCR }\end{array}$ & Symptoms $^{\mathrm{c}}$ \\
\hline \multicolumn{4}{|l|}{ Apocynaceae } \\
\hline Catharanthus roseus & $13 / 35$ & $4 / 5 ;+$ & St, Pr, V, Ph \\
\hline \multicolumn{4}{|l|}{ Brassicaceae } \\
\hline Brassica oleracea var. capitata & $6 / 6$ & $4 / 5 ;+$ & St, Y \\
\hline Brassica rapa var. akana & $0 / 4$ & $0 / 4 ;-$ & \\
\hline \multicolumn{4}{|l|}{ Compositae } \\
\hline Callistephus chinensis & $3 / 4$ & $3 / 3 ;+$ & St, Y \\
\hline \multicolumn{4}{|l|}{ Cucurbitaceae } \\
\hline Сиситis melo & $0 / 7$ & $0 / 4 ;-$ & \\
\hline \multicolumn{4}{|l|}{ Gramineae } \\
\hline Panicum miliaceum & $0 / 20$ & $0 / 5 ;-$ & \\
\hline Triticum aestivum & $44 / 44$ & $4 / 5 ;+$ & St, Y, Pr \\
\hline Secale cereale & $3 / 4$ & $3 / 4 ;+$ & St, Y, Pr \\
\hline \multicolumn{4}{|l|}{ Leguminosae } \\
\hline Phaseolus vulgaris & $0 / 5$ & $0 / 5 ;-$ & \\
\hline Vigna unguiculata & $0 / 12$ & $0 / 5 ;-$ & \\
\hline Medicago sativa & $15 / 20$ & $3 / 5 ;+$ & St, Y \\
\hline Trifolium repens & $5 / 10$ & $3 / 5 ;+$ & St, Y \\
\hline \multicolumn{4}{|l|}{ Solanaceae } \\
\hline Capsicum аппиит & $0 / 19$ & $0 / 4 ;-$ & \\
\hline Lycopersicon esculentum & $15 / 31$ & $3 / 5 ;+$ & St, Y, Ph \\
\hline \multicolumn{4}{|l|}{ Umbelliferae } \\
\hline Apium graveolens var. dulce & $0 / 9$ & $0 / 4 ;-$ & \\
\hline Daucus carota subsp. sativus & $0 / 30$ & $0 / 4 ;-$ & \\
\hline
\end{tabular}

\footnotetext{
a Total number of plants with symptoms/total number of plants inoculated.
}

${ }^{\mathrm{b}}$ Regular polymerase chain reaction (PCR) with primer pair R16mF2/R16mR1; total number of PCRpositive samples/total number of PCR-tested samples; +, PCR positive; -, PCR negative.

c Symptoms: St, stunt; Y, yellows; Pr, proliferation; V, virescence; Ph, phyllody. agent, and then transferred to healthy wheat seedlings (5 insects/seedling, 15 seedlings/trial) for 7 days before insect eradication with ethyl acetate. The transmission experiments were repeated three times independently in insect-proof greenhouses.

Investigation of host ranges and the WBD causal agent in natural weeds. Healthy $P$. striatus larvae were fed for 6 to 7 days on severely infected WBD wheat for acquisition of the casual agent, and then used to inoculate 16 species of plants from eight plant families, including wheat (Table 1). Each plant was inoculated with seven WBD-infected $P$. striatus larvae for 7 days. Disease symptoms were observed over a period of 40 to 45 days, and a polymerase chain reaction (PCR) assay was used to detect the $16 \mathrm{~S}$ rDNA of the WBD pathogenic agent.

Varieties of weeds with dwarfing and other abnormal growth symptoms were collected from areas close to WBD symptomatic wheat fields, and DNA was extracted, amplified by PCR, and analyzed by RFLP as described below for detection of possible phytoplasma infection. The weed species in the present investigation included goatgrass (Aegilops squarrosa), redroot amaranth (Amaranthus retroflexus), gmenlin's wormwood (Artemisia gmelinii), wild oat (Avena fatua), Japanese false bindweed (Calystegia hederacea), common cephalanoplos (Cephatanoplos segetum), aristate goosefoot (Chenopodium aristatum), oakleaf goosefoot (Chenopodium glaucum), flixweed tansymustard (Descurainia sophia), goosegrass (Eleusine indica), stink grass (Eragrostis cilianensis), wormseed mustard (Erysimum cheiranthoides), madwoman's milk (Euphorbia helioscopia), tender catchweed bedstraw (Gatium aparine var. tenerum), corn gromwell (Lithospermum arvense), common purslane (Portulaca oleracea), pale pigeongrass (Setaria glauca), common chickweed (Stellaria media), white clover (Trifolium repens), veronica (Veronica didyma), volunteer wheat seedlings (Triticum aestivum), and maize (Zea mays).

Nucleic acid extraction and PCR amplification. Total DNA was extracted from plants using the standard cetyltrimethyl ammonium bromide (CTAB) method (14). Insect samples were stored at $4^{\circ} \mathrm{C}$ for up to 2 weeks, or dried with anhydrous calcium chloride, until processed for total DNA extraction. Following a DNA extraction procedure previously described for insects (3), samples were ground individually in Eppendorf tubes in $500 \mu \mathrm{l}$ of preheated CTAB extraction buffer $(2 \%$ wt/vol CTAB, $1.4 \mathrm{M} \mathrm{NaCl}, 20 \mathrm{mM}$ EDTA, pH 8.0, $100 \mathrm{mM}$ Tris-HCl, $\mathrm{pH} 8.0$ ) with $0.2 \%$ $\beta$-mercaptoethanol, followed by incubation at $60^{\circ} \mathrm{C}$ for $30 \mathrm{~min}$, and extracted with chloroform-isoamyl alcohol (24:1). The aqueous DNA layer was precipitated with 
isopropanol, washed with $70 \%$ ethanol, and resuspended in $30 \mu \mathrm{l}$ of deionized water.

PCR reactions contained 50 to $100 \mathrm{ng}$ of total DNA template, $2 \mathrm{mM} \mathrm{MgCl}_{2}, 75 \mathrm{mM}$ Tris- $\mathrm{HCl} \quad\left(\mathrm{pH} \quad 8.8, \quad 25^{\circ} \mathrm{C}\right), \quad 20 \mathrm{mM}$ $\left(\mathrm{NH}_{4}\right)_{2} \mathrm{SO}_{4}, 0.01 \%$ (vol/vol) Tween 20, $200 \mu \mathrm{M}$ of each dNTP, $0.5 \mu \mathrm{M}$ of each primer, and $1.5 \mathrm{U} \mathrm{Taq}$ DNA polymerase in a total volume of $50 \mu \mathrm{l}$. Regular PCR or nested PCR was used for phytoplasma $16 \mathrm{~S}$ rRNA gene amplification. For regular PCR to detect phytoplasmas in insect materials, primer pair R16mF2/R16mR1 was used (10). For nested PCR amplifications of the phytoplasma 16S rRNA gene, two primer sets, R16mF1/R16mR1 and R16F2n/ R16R2, were used (10). PCR amplification was cycled 35 times with the following parameters: $95^{\circ} \mathrm{C}$ for $1 \mathrm{~min}, 55^{\circ} \mathrm{C}$ for 0.5 min, and $72^{\circ} \mathrm{C}$ for $1 \mathrm{~min}$ in a Thermocycler (PTC-200, Cepheid, Hercules, CA, USA). For nested PCR, $1 \mu \mathrm{l}$ of diluted (1:50) PCR product from Rl6mFl/R16mRl primer pair was used as the template. Primer pair $\mathrm{rpF} 1 / \mathrm{rpR} 1 \quad(22,23)$ was used for PCR amplification of the phytoplasma ribosomal protein genes (rps19, rpl22, and rps3).

DNA sequencing and phylogenetic analysis. A 1.4-kb PCR product using primer pair R16mF2/R16mR1 and a $1.2-\mathrm{kb}$ PCR fragment utilizing primer pair $\mathrm{rpF} 1 / \mathrm{rpR} 1$ were separately amplified from DNA samples extracted from WBD symptomatic plants and WBD-infected leafhoppers $(P$. striatus). The amplicons were purified and cloned. DNA sequence analysis was performed on both strands of the clones using an ABI Prism DNA sequencer (model 3730, ABI, Foster City, CA, USA). The nucleotide sequence data were analyzed by the Lasergene program (version 7.1.0, DNASTAR, Madison, WI, USA). The NCBI BLASTn program (version 2.2.19) was used to search the NCBI nucleotide collection ( $\mathrm{nr} / \mathrm{nt})$ database and align the query nucleotide sequences with other phytoplasma 16S rRNA and $r p s / r p l$ gene sequences $(1,25,41)$. A phylogenetic tree was constructed by the neighborjoining method using MEGA software version $4(29,34)$. The $16 \mathrm{~S}$ rRNA gene sequence of Escherichia coli (GenBank accession no. V00348) was used as an outgroup to root a phylogenetic tree. Bootstrapping was performed 1,000 times to estimate the confidence values of the branches in the phylogenetic tree.

RFLP analysis of PCR products. A 1.2-kb 16S rDNA fragment was amplified by nested PCR from 10 naturally infected plant species, WBD-inoculated wheat, and Catharanthus roseus, as well as PaWBinfected Paulownia fortunei and CWBinfected Melia azedarach. After purification, PCR products were digested separately by four restriction endonucleases, Sau3AI, RsaI, TaqI, and HhaI (18), according to the manufacturer's instructions (Fermentas, China). The digested PCR products were then separated by electrophoresis in $2 \%$ agarose gels or $8 \%$ PAGE gels, and stained with ethidium bromide.
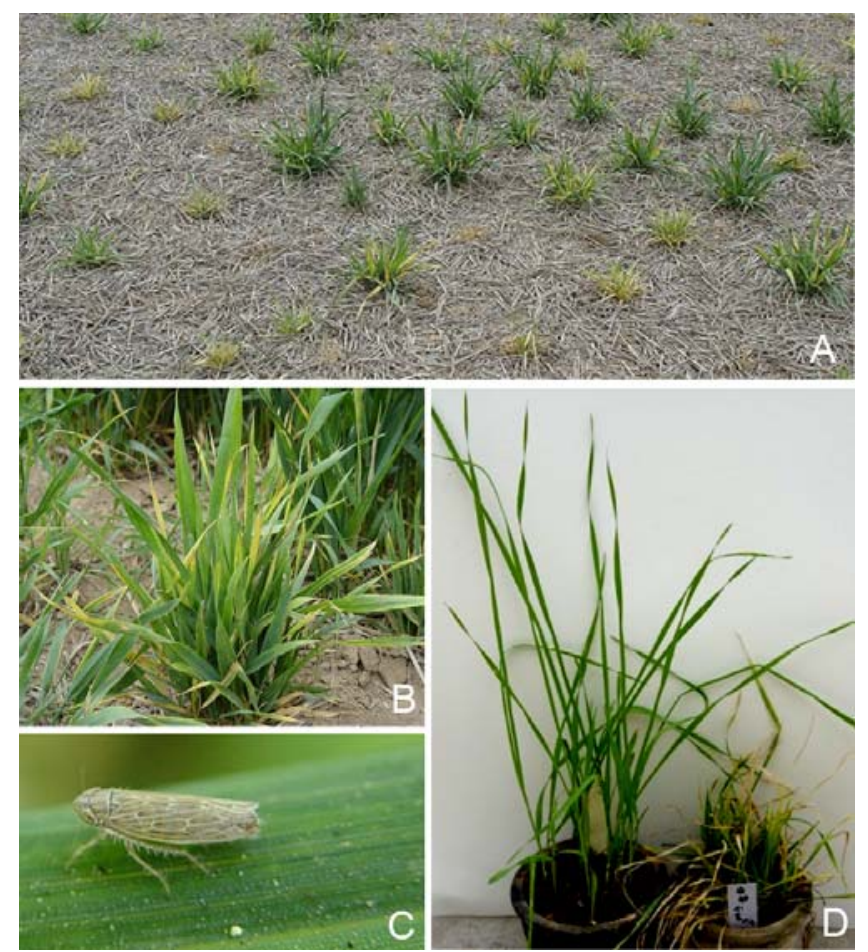

Fig. 1. Wheat blue dwarf disease (WBD) and its leafhopper vector. A, A severely WBD-infected wheat field in Hancheng, Shaanxi Province, China. B, Wheat seedlings with yellow leaf tip and dwarfing symptoms after WBD infection. C, Leafhopper Psammotettix stratus, the only identified leafhopper species that transmits WBD. D, Wheat seedlings experimentally inoculated by WBD-infected (right) and non-WBD-infected $P$. stratus leafhoppers (left).

RFLP profiles were visualized and photographed over a UV transilluminator.

\section{RESULTS}

WBD symptoms in winter wheat. Symptoms of the WBD disease appeared in winter wheat seedlings as early as the beginning of March in northwestern China (Shaanxi, Shanxi, and Gansu provinces). Initial symptoms included chlorotic mottling or curling of center leaves and slight dwarfing of the seedlings. Severe dwarfing with numerous short tillers developed at the base of the plants. Dark green or bluegreen streaks on leaves along with yellowing at the tips usually appeared in late March or early April. Yellowing and streaking of leaves faded gradually from April to May, but severely diseased plants remained yellow and stunted (Fig. 1A and B). Other symptoms such as rotten rhizomes, root death, and stem distortion could also be observed in some susceptible wheat varieties, such as Xiaoyan 6. Most affected plants remained severely dwarfed and produced sterile flowers or heads without grains. An obvious symptom of WBD was that the most diseased plants were less than one-third to one-half the height of healthy wheat and had fewer tillers. All leaves gradually became yellow and some eventually died.

WBD transmission by $\boldsymbol{P}$. striatus. To determine the WBD transmission vector, we tested leafhoppers $P$. striatus and $T$. viridis, and aphids A. gossypii, $M$. avenae, $M$. persicae, $R$. padi, $R$. maidis, and $S$. graminum. Among all insects tested, only P. striatus (Fig. 1C) transmitted the WBD agent from naturally infected wheat to healthy wheat seedlings. All 15 wheat seedlings showed typical WBD symptoms, such as dark blue streaks on leaves 2 weeks after infection and yellowish dwarfing and stunting 4 to 5 weeks after inoculation with $P$. striatus previously fed on WBD symptomatic wheat plants (Fig. 1D). Furthermore, about $70 \%$ of the WBDinfected $P$. striatus collected from diseased fields transmitted the disease agent to healthy wheat seedlings without an acquisition feeding procedure (data not shown).

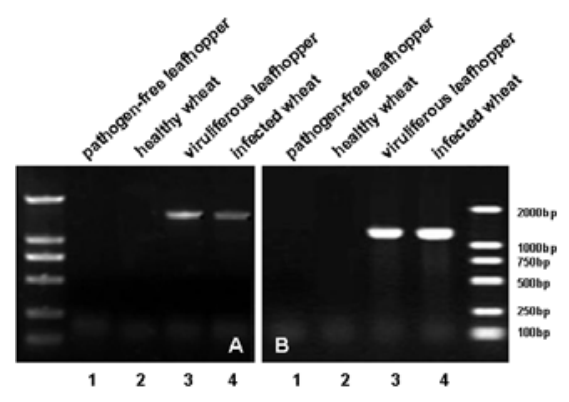

Fig. 2. Polymerase chain reaction amplification of $16 \mathrm{Sr}$ RNA and $r p s / r p l$ gene fragments of wheat blue dwarf disease phytoplasma. A, 16S rRNA gene fragment. B, rp19, rpl22, and rps3 gene fragment. M: DNA Marker DL2000 (Takara, Japan). 
In contrast, the other insect species tested, $T$. viridis, $R$. padi, S. graminum, M. avenae, $R$. maidis, $M$. persicae, and A. gossypii, failed to transmit WBD, either directly or after an acquisition feeding procedure under controlled conditions (data not shown).

Identification of the WBD phytoplasma by sequence analysis of the $16 \mathrm{~S}$ rDNA and ribosomal protein genes. To detect and identify phytoplasmas in the WBD-infected wheat samples and WBDinfected leafhoppers, PCR assays were conducted utilizing phytoplasma-specific primers targeting the $16 \mathrm{~S}$ rRNA and ribosomal protein gene sequences $(10,22)$. With primer pair R16mF2/R16mR1 targeted to the $16 \mathrm{~S}$ rRNA gene, a PCR frag- ment with the expected size of $1.4 \mathrm{~kb}$ was amplified from three DNA samples extracted from three different WBD-infected wheat samples that were collected from wheat fields in Hancheng, Shaanxi Province (Fig. 2A). No PCR amplicons were produced from control samples of healthy wheat plants (Fig. 2A). The same 1.4-kb DNA fragment was also amplified from 7 of 13 wheat seedlings that were inoculated with WBD-infected leafhoppers. These WBD-infected leafhoppers had been fed for 2 or 3 days on WBD symptomatic wheat plants for acquisition of the phytoplasma pathogen in the greenhouse, and the wheat seedlings subsequently displayed WBD symptoms (data not shown). These results indicated an intimate asso- ciation between the phytoplasma and WBD disease. The 16S rDNA fragment was also amplified from 2 of 16 DNA samples extracted from individual $P$. striatus leafhoppers that were collected from wheat fields but not from the pathogenfree leafhopper colonies reared in the greenhouse (Fig. 2A).

For analysis of the ribosomal protein genes, a DNA fragment of approximately $1.2 \mathrm{~kb}$, containing a partial S19 gene (rps19) and complete L22 (rpl22) and S3 (rps3) genes, was amplified by PCR with primer pair rpF1/rpR1 (22,23). This 1.2-kb amplicon was observed in the same DNA samples from the WBD-infected plants and insects as stated as above, including the field-infected wheat and field-collected

Table 2. 16S rDNA and $r p s / r p l$ gene sequence identities between the wheat blue dwarf disease (WBD) phytoplasma and related phytoplasmas

\begin{tabular}{|c|c|c|c|c|c|c|}
\hline \multirow[b]{2}{*}{$\begin{array}{l}\text { Group and } \\
\text { subgroup }\end{array}$} & \multirow[b]{2}{*}{ Acronyms } & \multirow[b]{2}{*}{ Disease caused } & \multicolumn{2}{|c|}{ 16S rDNA } & \multicolumn{2}{|c|}{ rps 19, rpl22 and rps3 gene } \\
\hline & & & $\begin{array}{c}\text { GenBank } \\
\text { accession no. }\end{array}$ & $\begin{array}{c}\text { Nt identity }(\%) \text { to } \\
\text { WBD (GenBank } \\
\text { DQ078304) }\end{array}$ & $\begin{array}{c}\text { GenBank } \\
\text { accession no. }\end{array}$ & $\begin{array}{c}\text { Nt identity (\%) to } \\
\text { WBD (GenBank } \\
\text { EF417591) }\end{array}$ \\
\hline 16SrI-A & TBB & Tomato big bug & L33760 & 99.2 & & \\
\hline 16SrI-A & HYDP & Hydrangea phyllody & & & AY264868 & 96.6 \\
\hline 16SrI-A & OatP & Oat proliferation & AF453416 & 99.2 & & \\
\hline 16SrI-B & $\mathrm{HP}$ & Hydrangea phyllody & AY265207 & 99.4 & & \\
\hline $16 \mathrm{SrI}-\mathrm{B}$ & AY & Aster yellows & AY180952 & 99.4 & & \\
\hline $16 \mathrm{SrI}-\mathrm{B}$ & MBS & Maize bushy stunt & AY265208 & 99.4 & AY264858 & 96.9 \\
\hline $16 \mathrm{SrI}-\mathrm{B}$ & BaDef & Barley deformation & AY734453 & 99.4 & AY735448 & 97.3 \\
\hline 16SrI-B & SAY & Western aster yellows SAY & M86340 & 99.2 & & \\
\hline $16 \mathrm{SrI}-\mathrm{C}$ & $\mathrm{CPhA}$ & Clover phyllody strain rrnA & AF222065 & 99.9 & AY264862 & 99.6 \\
\hline $16 \mathrm{SrI}-\mathrm{C}$ & $\mathrm{CPhB}$ & Clover phyllody strain rrnB & AF222066 & 99.7 & & \\
\hline $16 \mathrm{SrI}-\mathrm{C}$ & KVE & Clover phyllody strain KVE & AY265217 & 99.7 & AY264861 & 99.5 \\
\hline $16 \mathrm{SrI}-\mathrm{C}$ & KVG & Clover phyllody strain KVG & AY265218 & 99.7 & AY264860 & 99.7 \\
\hline 16SrI-D & PaWB & Paulownia witches'-broom & AY265206 & 99.2 & AY902910 & 96.8 \\
\hline 16SrI-D & PaWB & Paulownia witches'-broom & & & AY662673 & 96.8 \\
\hline 16SrI-E & BBS & Blueberry stunt & AY265220 & 99.2 & AY264863 & 96.9 \\
\hline $16 \mathrm{SrI}-\mathrm{F}$ & ACLR-AY & Apricot chlorotic leaf roll & AY265211 & 98.9 & & \\
\hline $16 \mathrm{SrI}-\mathrm{B}$ & CWB-HN & Chinaberry witches'-broom & & & EU348781 & 96.9 \\
\hline $16 \mathrm{SrI}-\mathrm{B}$ & CWB-WSh & Chinaberry witches'-broom & & & DQ648460 & 96.7 \\
\hline $16 \mathrm{SrI}-\mathrm{B}$ & CWB-GZh & Chinaberry witches'-broom & & & DQ648461 & 96.8 \\
\hline $16 \mathrm{SrI}$ & MDNY & Mulberry dwarf & & & FJ154858 & 97.3 \\
\hline $16 \mathrm{SrII}$ & PEY & Picris echioides phyllody & & & EF186802 & 63.9 \\
\hline $16 \mathrm{SrII}$ & PnWB & Peanut witches'-broom & L33765 & 88.6 & & \\
\hline 16SrIII & $\mathrm{CX}$ & Peach X-disease & & & EF186813 & 60.9 \\
\hline 16 SrIII & $\mathrm{SP}$ & Spirea stunt & & & EF186806 & 61.2 \\
\hline 16 SrIII & MWI & Milkweed yellows & & & EF186808 & 63.4 \\
\hline 16 SrIII & WX & Western X phytoplasma & L04682 & 90.0 & & \\
\hline 16SrIV & CLY & Coconut lethal yellowing & U18747 & 90.1 & & \\
\hline $16 \mathrm{SrV}$ & $\mathrm{EY}$ & Elm yellow & AF189214 & 90.2 & & \\
\hline 16SrVI & CPS & Catharanthus phyllody & & & EF183494 & 62.4 \\
\hline 16SrVI & PWB & Potato witches'-broom & & & EF183487 & 63 \\
\hline $16 \mathrm{SrVI}$ & PWB & Potato witches'-broom & & & AY 197683 & 63 \\
\hline 16SrVI & $\mathrm{CP}$ & Clover proliferation & & & EF183486 & 63 \\
\hline 16SrVI & $\mathrm{CP}$ & Clover proliferation & AY390261 & 90.3 & & \\
\hline 16SrVII & AshY & Ash yellows & X68339 & 89.6 & EF183492 & 61.9 \\
\hline 16SrVIII & LfWB & Loofah witches'-broom & AF353090 & 90.8 & & \\
\hline 16SrIX & AlmWB-A112 & Almond witches'-broom & & & EF186803 & 65 \\
\hline 16 SrIX & KAP & Knautia arvensis & & & EF186801 & 63.8 \\
\hline 16 SrIX & GLLhon & Gliricidia little leaf & & & EF186800 & 62.4 \\
\hline 16SrIX & PPWB & Pigeon pea witches'-broom & AF248957 & 88.7 & EF193383 & 64.8 \\
\hline $16 \mathrm{SrX}$ & AP & Apple proliferation & X68375 & 91.6 & & \\
\hline $16 \mathrm{SrXI}$ & RYD & Rice yellow dwarf & D12581 & 89.4 & & \\
\hline $16 \mathrm{SrXII}$ & STOL & Stolbur & X76427 & 96.0 & & \\
\hline 16SrXIII & GRI & Goldenrod yellows & & & EF186810 & 61.3 \\
\hline 16SrXIII & WWB & Walnut witches'-broom & & & EF186812 & 60.3 \\
\hline 16SrXIII & MPV & Mexican periwinkle virescence & AF248960 & 96.0 & & \\
\hline 16SrXIV & BGWL & Bermuda grass white leaf & AJ550984 & 90.0 & & \\
\hline $16 \mathrm{SrXV}$ & HWB & Hibiscus witches'-broom & AF 147708 & 88.9 & & \\
\hline 16SrXVI & $\mathrm{ScYL}$ & Sugarcane yellow leaf & AY725228 & 93.5 & & \\
\hline $16 \mathrm{SrXVII}$ & PBT & Papaya bunchy top & AY725234 & 92.3 & & \\
\hline 16SrXVIII & PPT & Nebraska potato purple top & DQ174122 & 95.2 & & \\
\hline
\end{tabular}


WBD-infected $P$. striatus, but not from the corresponding controls (healthy wheat plants and pathogen-free $P$. striatus colonies) (Fig. 2B).

To confirm that the PCR fragments described above were derived from phytoplasmas, four of the 1.4-kb (16S rDNA) and four of the 1.2-kb (rps19/rpl22/rps3) PCR fragments from two field-infected wheat samples and two WBD-infected $P$. striatus, respectively, were cloned and sequenced. Nucleotide sequence analysis revealed that the entire 1,432 nucleotides of the 1.4-kb fragments from field WBD wheat samples and WBD-infected $P$. striatus with primer pair $\mathrm{R} 16 \mathrm{mF} 2 / \mathrm{R} 16 \mathrm{mR} 1$ were identical in sequence (GenBank ac- cession no. DQ078304). A BLASTn search showed that the WBD 1,432-bp fragment shared highest nucleotide identities with $16 \mathrm{~S}$ rDNAs from aster yellows group (16SrI) phytoplasmas. The pairwise identities of the $16 \mathrm{~S}$ rDNA genes between WBD and 14 selected strains of the $16 \mathrm{SrI}$ group ranged from 98.9 to $99.9 \%$, whereas nucleotide identities between WBD and 17 other phytoplasma groups (16SrII to 16SrXVIII) ranged from 88.6 to $96.0 \%$ (Table 2).

The 1.2-kb PCR fragments from fieldcollected WBD wheat samples and WBDinfected $P$. striatus with primer pair rpF1/rpR1 consisted of the same 1,240 nucleotides (GenBank accession no.
EF417591). Sequence analysis showed that pairwise nucleotide identities ranged from 96.6 to $99.7 \%$ between WBD and nine selected strains in the aster yellows group (16SrI), but only from 60.3 to $65 \%$ between WBD and other phytoplasma groups (Table 2). Therefore, both 16S rDNA and $r p s / r p l$ gene sequence comparisons suggest that the WBD phytoplasma is a member of the aster yellows group (16SrI) $(18,19,26,38)$.

In the phytoplasma 16SrI group, the WBD 16S rRNA gene nucleotide sequence has 99.7 to $99.9 \%$ identity to four clover phyllody $(\mathrm{CPh})$ phytoplasmas, the representative strains of the $16 \mathrm{SrI}-\mathrm{C}$ subgroup (Table 2). The nucleotide identities within

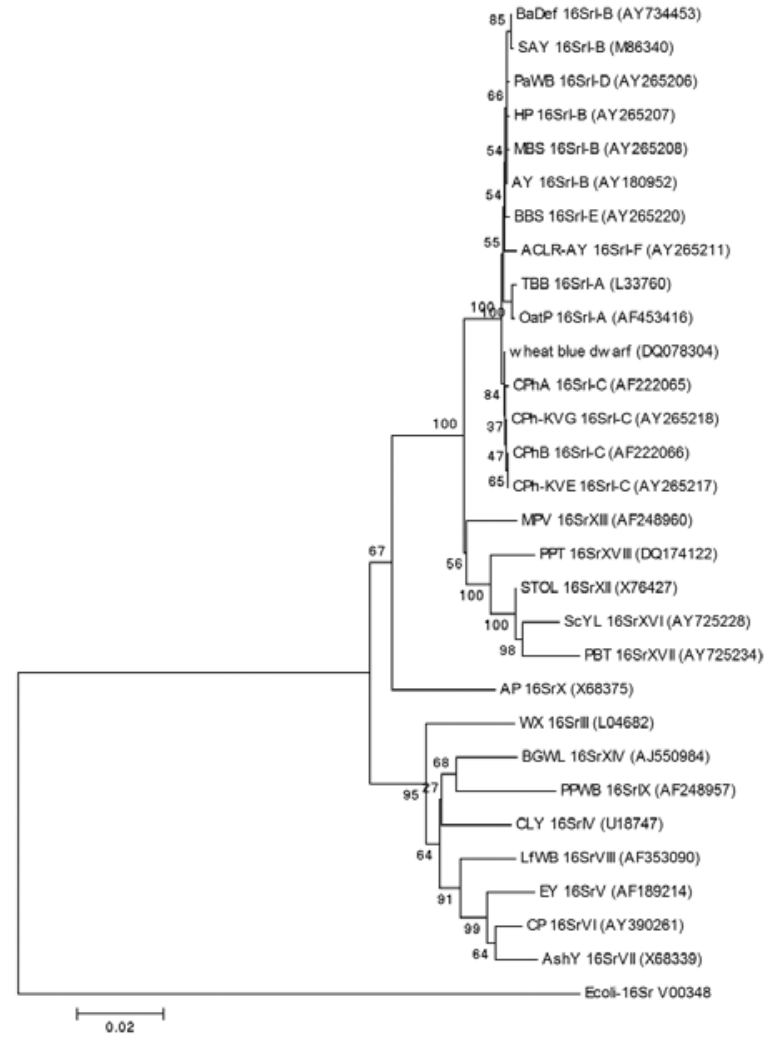

Fig. 3. Phylogenetic tree constructed by parsimony analysis of $16 \mathrm{~S}$ rDNA sequences from wheat blue dwarf disease (GenBank accession no. DQ078304) and 28 other phytoplasmas using the neighbor-joining method. Bootstrap values (expressed as percentages of 1,000 replications) are shown, and branch lengths are proportional to the number of inferred character state transformations. Bar = substitutions per base. The $16 \mathrm{~S}$ rRNA sequence of Escherichia coli (GenBank accession no. V00348) was used as an outgroup. Abbreviations of phytoplasmas, with GenBank accession numbers, are defined as follows: barley deformation (BaDef, AY734453), western aster yellows SAY (SAY, M86340), Paulownia witches'-broom (PaWB, AY265206), hydrangea phyllody (HP, AY265207), maize bushy stunt (MBS, AY265208), aster yellows (AY, AY180952), blueberry stunt (BBS, AY265220), apricot chlorotic leaf roll (ACLR-AY, AY265211), tomato big bug (TBB, L33760), oat proliferation (OatP, AF453416), wheat blue dwarf (WBD, DQ078304), clover phyllody strain $\mathrm{rnA}$ (CPhA, AF222065), clover phyllody strain KVG (KVG, AY265218), clover phyllody strain rmB (CPhB, AF222066), clover phyllody strain KVE (KVE, AY265217), Mexican periwinkle virescence (MPV, AF248960), Nebraska potato purple top (PPT, DQ174122). stolbur (STOL, X76427), sugarcane yellow leaf (ScYL, AY725228), papaya bunchy top (PBT, AY725234), apple proliferation (AP, X68375), western X phytoplasma (WX, L04682), Bermuda grass white leaf (BGWL, AJ550984), pigeon pea witches'broom (PPWB, AF248957), coconut lethal yellowing (CLY, U18747), loofah witches'-broom (LfWB, AF353090), elm yellow (EY, AF189214), clover proliferation (CP, AY390261), ash yellows (AshY, X68339).
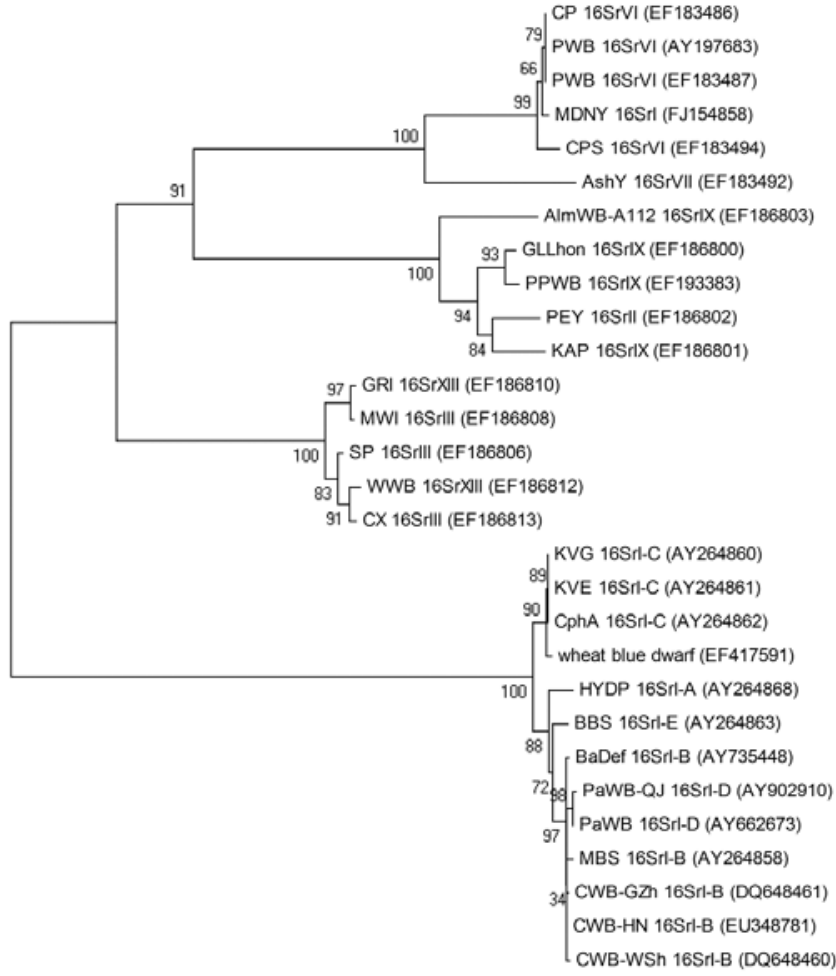

0.05

Fig. 4. Phylogenetic tree constructed by parsimony analysis of $r p 19$, rpl22, and rps3 gene sequences from wheat blue dwarf disease (GenBank accession no. EF417591) and 28 other phytoplasmas using the neighbor-joining method. Bootstrap values (expressed as percentages of 1,000 replications) are shown, and branch lengths are proportional to the number of inferred character state transformations. Bar = substitutions per base. Abbreviations of phytoplasmas, with GenBank accession numbers, are defined as follows: potato witches'-broom (PWB, EF183487 and AY197683), clover proliferation (CP, EF183486), mulberry dwarf (MDNY, FJ154858), Catharanthus phyllody (CPS, EF183494), ash yellows (AshY, EF183492), almond witches'-broom (AlmWB-A112, EF186803), Gliricidia little leaf (GLLhon, EF186800), pigeon pea witches'-broom (PPWB, EF193383), Picris echioides phyllody (PEY, EF186802), Knautia arvensis (KAP, EF186801), goldenrod yellows (GRI, EF186810), milkweed yellows (MWI, EF186808), spirea stunt (SP, EF186806), walnut witches'-broom (WWB, EF186812), peach X-disease (CX, EF186813), clover phyllody strain KVG (KVG, AY264860), clover phyllody strain KVE (KVE, AY264861), clover phyllody strain rrnA (CPhA, AY264862), wheat blue dwarf (WBD, EF417591), hydrangea phyllody (HYDP, AY264868), blueberry stunt (BBS, AY264863), barley deformation (BaDef, AY735448), Paulownia witches'-broom (PaWB, AY902910 and AY662673), maize bushy stunt (MBS, AY264858), chinaberry witches'-broom (CWB, EU348781, DQ648460, and DQ648461). 
the $16 \mathrm{SrI}-\mathrm{C}$ isolate phytoplasmas, including $\mathrm{CPhA}, \mathrm{CPhB}, \mathrm{CPh}-\mathrm{KVG}$, and $\mathrm{CPh}-$ KVE, are also between 99.7 to $99.9 \%$. The homology of the WBD phytoplasma to strains from the other 16SrI subgroups was $\leq 99.4 \%$ (Table 2). The WBD rps19, rpl22, and rps3 gene nucleotide sequences had 99.5 to $99.7 \%$ identity to three clover phyllody $(\mathrm{CPh})$ phytoplasmas, whereas the homology of WBD phytoplasma to isolates in other 16SrI subgroups was less than 97.3\% (Table 2). These results indicate related to the $16 \mathrm{SrI}-\mathrm{C}$ subclade. Phylogenetic analysis of 16S rRNA genes and rps 19, rpl22, and rps3 genes was also performed, using nucleotide sequence alignments of the WBD phytoplasma with phytoplasma strains from the other 18 phylogenetic groups. As shown in Figures 3 and 4 , the phylogenetic trees revealed that the WBD phytoplasma grouped with strains from the 16SrI group in one monographic cluster, distinct from strains of other phytoplasma groups. In the $16 \mathrm{SrI}$ cluster, the WBD phytoplasma was localized in the subcluster 16SrI-C, suggesting that it is evolutionarily closest to the four clover phyllody phytoplasma strains (CPhA, CPh-KVG, CPhB, and CPh-KVE). that the WBD phytoplasma is most closely

Host range of the WBD phytoplasma. We inoculated 16 plant species from eight families through transmission trials of WBD-infected $P$. striatus under controlled conditions in a greenhouse. Symptom development was observed over a period of 40 to 45 days post-WBD inoculation. Three to five plants of each species were tested to confirm WBD phytoplasma infections by PCR assays of the $16 \mathrm{~S}$ rRNA gene using primer pair R16mF2/R16mR1 (10). The results are summarized in Table 1 . We observed disease symptoms and positive PCR amplification of the phytoplasmal 16S rRNA gene in eight species of seven families, including Callistephus chinensis, Catharanthus roseus, Brassica oleracea var. capitata, Lycopersicon esculentum, Medicago sativa, Secale cereale, Trifolium repens, and Triticum aestivum (Table 1). The main symptoms of infected plants were stunting and yellowing in $C$. chinensis, B. oleracea var. capitata, $M$. sativa, and $T$. repens; stunting, yellowing, and proliferation of shoots in L. esculentum, $S$. cereale, and $T$. aestivum; and stunting, yellowing, proliferation, and virescence in C. roseus (Table 1). However, no WBD phytoplasmas were detected in the other eight plant species tested, including Bras-

Table 3. Polymerase chain reaction (PCR) detection of the wheat blue dwarf disease (WBD) phytoplasma in weed species growing in or adjacent to WBD-infected wheat fields

\begin{tabular}{|c|c|c|}
\hline \multirow[b]{2}{*}{ Weeds } & \multicolumn{2}{|c|}{$\mathbf{P C R}^{\mathbf{a}}$} \\
\hline & Directed-PCR & Nested-PCR \\
\hline \multicolumn{3}{|l|}{ Amaranthaceae } \\
\hline Amaranthus retroflexus & $4 / 5 ;+$ & $5 / 5 ;+$ \\
\hline \multicolumn{3}{|l|}{ Apocynaceae } \\
\hline Calystegia hederacea & $0 / 4 ;-$ & $0 / 4 ;-$ \\
\hline \multicolumn{3}{|l|}{ Boraginaceae } \\
\hline Lithospermum arvense & $0 / 3 ;-$ & $2 / 3 ;+$ \\
\hline \multicolumn{3}{|l|}{ Brassicaceae } \\
\hline Erysimum cheiranthoides & $0 / 4 ;-$ & $3 / 4 ;+$ \\
\hline \multicolumn{3}{|l|}{ Caryophyllaceae } \\
\hline Stellaria media & $0 / 5 ;-$ & $0 / 5 ;-$ \\
\hline \multicolumn{3}{|l|}{ Chenopodiaceae } \\
\hline Chenopodium aristatum & $0 / 4 ;-$ & $0 / 4 ;-$ \\
\hline Chenopodium glaucum & $0 / 4$ & $0 / 4$ \\
\hline \multicolumn{3}{|l|}{ Compositae } \\
\hline Artemisia gmelinii & $0 / 4 ;-$ & $0 / 4 ;-$ \\
\hline Cephatanoplos segetum & $0 / 4 ;-$ & $0 / 4 ;-$ \\
\hline Descurainia sophia & $3 / 5 ;+$ & $3 / 5 ;+$ \\
\hline \multicolumn{3}{|l|}{ Euphorbiaceae } \\
\hline Euphorbia helioscopia & $0 / 3 ;-$ & $0 / 3 ;-$ \\
\hline \multicolumn{3}{|l|}{ Gramineae } \\
\hline Aegilops squarrosa & $2 / 3 ;+$ & $3 / 3 ;+$ \\
\hline Avena fatua & $3 / 4 ;+$ & $3 / 4 ;+$ \\
\hline Eleusine indica & $0 / 3 ;-$ & $0 / 3 ;-$ \\
\hline Eragrostis cilianensis & $3 / 4 ;+$ & $4 / 4 ;+$ \\
\hline Setaria glauca & $0 / 4$ & $0 / 4 ;-$ \\
\hline Triticum aestivum & $1 / 3 ;+$ & $3 / 3 ;+$ \\
\hline Zea mays & $0 / 3 ;-$ & $0 / 3 ;-$ \\
\hline \multicolumn{3}{|l|}{ Leguminosae } \\
\hline Trifolium repens & $3 / 5 ;+$ & $4 / 5 ;+$ \\
\hline \multicolumn{3}{|l|}{ Portulacaceae } \\
\hline Portulaca oleracea & $0 / 4 ;-$ & $0 / 4 ;-$ \\
\hline \multicolumn{3}{|l|}{ Rubhceae } \\
\hline Gatium aparine var. tenerum & $0 / 5 ;-$ & $0 / 5 ;-$ \\
\hline \multicolumn{3}{|l|}{ Scrophulariaceae } \\
\hline Veronica didyma & $2 / 4 ;+$ & $3 / 4 ;+$ \\
\hline
\end{tabular}

sica rapa var. akana, Capsicum annuum, Cucumis melo, Panicum miliaceum, Phaseolus vulgaris, Vigna unguiculata, Apium graveolens var. dulce, and Daucus carota subsp. sativus (Table 1).

We also surveyed various weed species near WBD-infected wheat fields for the presence of the WBD phytoplasma by directed PCR or nested PCR, and subsequent PCR-RFLP analysis. In total, 22 weed species from 13 families were subjected to molecular diagnosis of the WBD phytoplasma (Table 3). These selected weed plants showed abnormal growth symptoms, including shortened internodes, proliferation of shoots, stunting, leaf distortion, virescence, and other typical symptoms that would usually be caused by phytoplasmas. Results by direct PCR using primer pair R16mF2/R16mR1, or a nested PCR using a second primer pair R16F2n/R16R2 are summarized in Table 3 . Ten plant species in seven families were positive for the presence of the WBD phytoplasma, including redroot amaranth (Amaranthus retroflexus), corn gromwell (Lithospermum arvense), flixweed tansymustard (Descurainia sophia), wormseed mustard (Erysimum cheiranthoides), goatgrass (Aegilops squarrosa), wild oat (Avena fatua), stink grass (Eragrostis cilianensis), volunteer wheat seedlings (Triticum aestivum), white clover (Trifolium repens), and veronica (Veronica didyma) (Table 3). Lithospermum arvense and Erysimum cheiranthoides were negative for the presence of phytoplasmas by directed PCR, but positive by nested PCR analysis, suggesting they contain lower levels of phytoplasmas than the other eight positive weed species. Although displaying abnormal growth symptoms, 12 other weed species were found to be negative for phytoplasmas by PCR, indicating the disease symptoms might be caused by other pathogenic agents and not phytoplasmas (Table 3).

To determine if phytoplasmas in the 10 PCR-positive weed species were the WBD phytoplasma, we performed RFLP analysis following nested PCR amplification of the 1.2-kb 16S rDNA fragments. Restriction endonuclease digestion with Sau3AI, RsaI, and TaqI, which distinguish 16 SrI phytoplasmas from those belonging to other phylogenetic groups (18), produced RFLP patterns that were the same among all samples with the fragments predicated from the WBD and PaWB phytoplasmic 16S rDNA sequences (Fig. 5). The results suggested that the 10 weed species were naturally infected by a $16 \mathrm{SrI}$ group phytoplasma. Apart from being identical to PaWB, the RFLP profiles obtained with Sau3AI, RsaI, and TaqI are also the same as those reported previously for aster yellows (AY) phytoplasma $(17,18)$, providing additional evidence that WBD phytoplasma is closely related to the phytoplasma strains in the 16SrI group. Enzyme 
HhaI can be used to distinguish subgroup 16SrI-C phytoplasmas from other AY phytoplasmas (18). HhaI digestion of $16 \mathrm{~S}$ rDNA fragments amplified from the 10 field-collected weed samples all revealed a similar pattern to those from WBDinfected $C$. roseus, but different from chinaberry witches'-broom (CWB, 16SrI-B) (21) and PaWB (16SrI-D) (18,32) (Fig. 5). The RFLP profile obtained with HhaI was also the same as those reported previously for 16SrI-C phytoplasmas (18). These results indicate that the weeds collected from the WBD-infected wheat field areas were most likely infected with the WBD phytoplasma.

\section{DISCUSSION}

In the present study, we have provided evidence that WBD, which frequently affects winter wheat in northwestern areas of China, is caused by a phytoplasmal agent transmitted by the leafhopper Psammotettix striatus. Phylogenetic analy- ses based on both 16S rRNA and ribosomal protein gene sequences revealed that WBD phytoplasma is a member of the aster yellows (AY) group (16SrI) and most closely related to $\mathrm{CPh}$ phytoplasmas in subgroup 16SrI-C. The AY group (16SrI) is the most diverse and widespread phytoplasma group and causes more than 100 plant diseases, making this disease economically important throughout the world. Over 100 isolates of AY phytoplasmas have been examined and classified into 15 subgroups based on RFLP analysis of their $16 \mathrm{~S}$ rDNA sequences $(9,19,26)$. The phytoplasmas of subgroup 16SrI-C have been reported to infect many herbaceous plant species, including clovers, buttercup, common meadow grass, tall fescue, and strawberry; as well as woody plant species, including grapevines, apple trees, olive, lilies, eucalyptus, and European hackberry $(6,7,14,37)$. However, there are no previous reports of subgroup 16SrI-C strains infecting small grain crops, including wheat. The 16 SrI-C phytoplasmas employ a number of insect vectors including Aphrodes bicincta, Euscelidius variegatus, Euscelis lineolatus, Macrosteles cristata, Macrosteles viridigriseus, and Paraphlepsius irroratus (www.ipwgnet.org) (8), but $P$. striatus has not previously been shown to transmit any phytoplasmas from this subgroup. It was previously reported in China $(39,43)$ that $P$. striatus was an essential leafhopper vector for transmission of WBD, but until our present study it had not been proven that this disease was caused by a phytoplasma.

Several phytoplasmas that affect cereal crops have been investigated previously, including Western severe aster yellows (SAY) (15,20), Eastern aster yellows (NAY) (20), maize bushy stunt (MBS) $(12,18)$, oat proliferation (OatP) $(13)$, oat yellows (OatY) (36), barley deformation (BaDef) (36), and Triticosecale stunt (TrSt) (36). Interestingly, these all belong to the AY group (16SrI). SAY and NAY
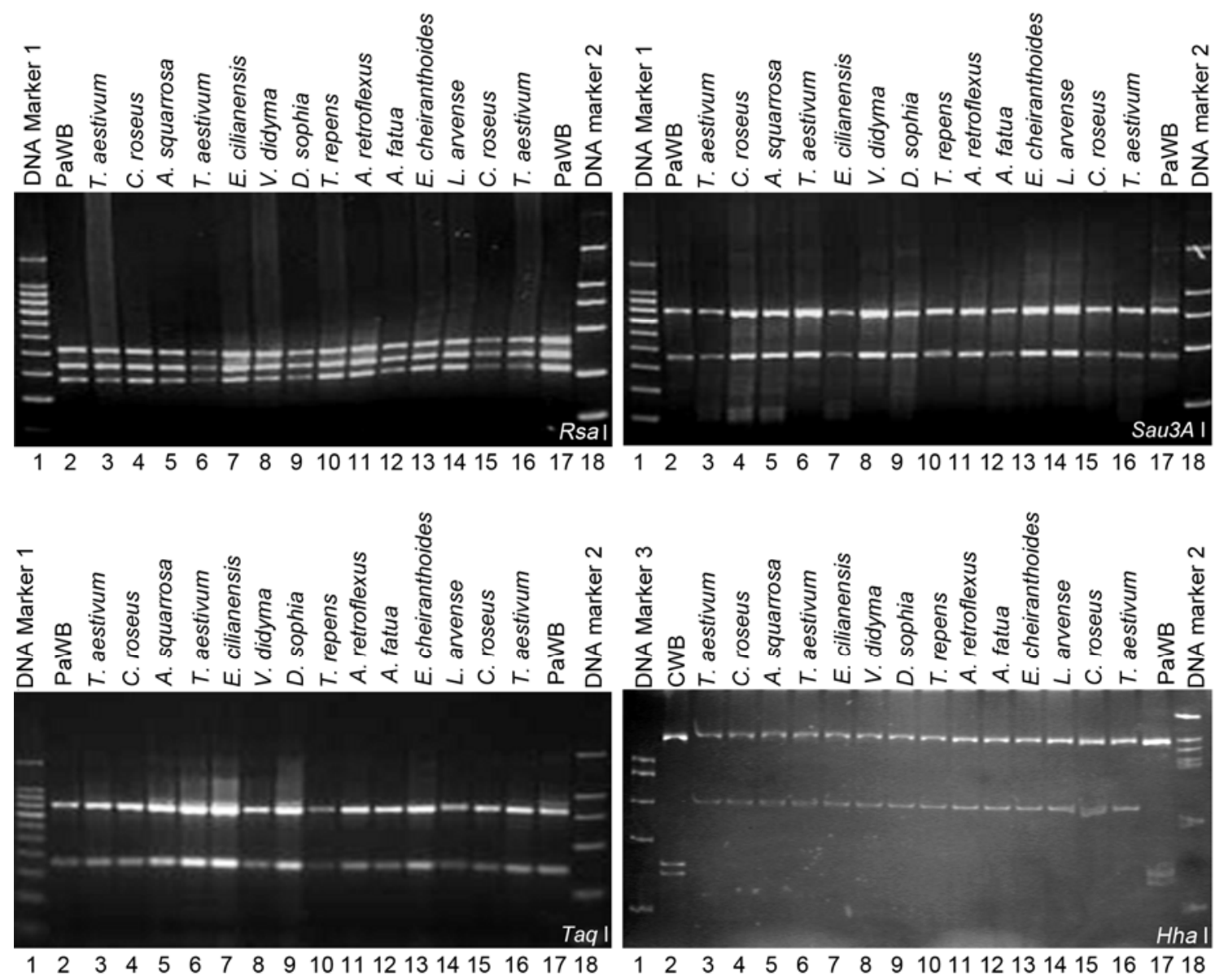

Fig. 5. Restriction fragment length polymorphism (RFLP) analysis of $16 \mathrm{~S}$ rDNA sequences amplified by nested polymerase chain reaction (PCR) with primer pairs R16mF2/R16mR1 followed by R16F2/R16R2 from 10 naturally infected plant species. PCR products were digested with Sau3AI, RsaI, TaqI, and HhaI. Digestion products were then separated by electrophoresis in 2\% agarose gels (for Sau3AI, RsaI, and TaqI) or 8\% PAGE gel (for HhaI). Lanes 1 and 18, DNA marker, marker 1: DNA 100-bp ladder marker (Takara, Japan), marker 2: DNA Marker DL2000 (Takara, Japan), marker 3: DNA Marker I (Bioteke, China); 2 (for Sau3AI, RsaI, and TaqI), PaWB (Paulownia witches'-broom) infected Royal Paulownia (Paulownia fortunei); 2 (for HhaI), CWB (chinaberry witches'-broom phytoplasma) infected Melia azedarach; 3 and 16, wheat inoculated with wheat blue dwarf disease (WBD) in the laboratory; 4 and 15, Catharanthus roseus inoculated with WBD in the laboratory; 5, goatgrass (Aegilops squarrosa); 6, volunteer wheat seedlings (Triticum aestivum); 7 , candygrass (Eragrostis cilianensis); 8, veronica (Veronica didyma); 9, flixweed tansymustard (Descurainia sophia); 10, clover (Trifolium repens); 11, amaranth pigweed (Amaranthus retroflexus); 12, wild oat (Avena fatua); 13, wormseed mustard (Erysimum cheiranthoides); 14, corn gromwell (Lithospermum arvense); 17, PaWB (Paulownia witches'-broom) infected Royal Paulownia (Paulownia fortunei). 
were reported to cause severe yield losses in wheat and barley in Canada (7). MAS affects corn varieties in North America and Brazil (5). OatP and OatY are phytoplasma-associated diseases occurring in oat crops in Lithuania $(13,36)$. BaDef and TrSt are two phytoplasma diseases affecting barley and Triticosecale (Triticum $\times$ Secale) in Lithuania $(35,36)$. Based on RFLP and phylogenetic analyses of $16 \mathrm{~S}$ rRNA and rps19, rpl22, and rps3 gene sequences, NAY and OatP have been identified as 16SrI-A phytoplasmas, while SAY, MAS, OatY, BaDef, and TrSt are classified in the 16SrI-B subgroup $(13,35,36)$. We compared available $16 \mathrm{~S}$ rRNA and rps19, rpl22, and rps3 gene sequences between WBD and these phytoplasmas and found that the pairwise identity of $16 \mathrm{~S}$ rDNA between WBD and the other cereal phytoplasmas were 99.2 to $99.4 \%$, which is less than the 99.7 to $99.9 \%$ identity of WBD to the 16 SrI-C subgroup strains (Table 2). A similar relationship was obtained from comparison of the rps19, rpl22, and rps3 genes. Nucleotide sequence identities of the rps19, rpl22, and rps3 genes were 96.9 to $97.3 \%$ between WBD and the other cereal phytoplasmas, which was significantly lower than the identity of 99.5 to $99.7 \%$ between WBD and 16SrI-C phytoplasmas (Table 2). Phylogenetic trees based on these sequence comparisons also indicated that WBD is phylogenetically closer to the 16 SrI-C subgroup than to any other $16 \mathrm{SrI}$ subgroups, which include the other cereal phytoplasmas (Figs. 3 and 4).

$P$. striatus was previously reported to be infected by the grapevine Stolberg (STOL) 16SrXII phytoplasma (4). However, except for the WBD phytoplasma, P. striatus was not reported to transmit other cereal cropassociated phytoplasmas. P. striatus is a predominant Cicadellidae in wheat fields in Shaanxi and Gansu provinces of northwestern China. It can produce four generations a year and is able to adapt to 18 species of gramineous crops and weeds (40). A previous survey from our laboratory found that the severity of WBD in the field was correlated with high populations of $P$. striatus (24). The present study demonstrated that WBD is exclusively transmitted by $P$. striatus. PCR assays, with both $16 \mathrm{~S}$ rDNA and $r p s / r p l$ gene primers, successfully identified the WBD pathogen as a phytoplasma and detected it in infected wheat, weeds, and WBD-infected $P$. striatus. Therefore, PCR-based molecular techniques can provide a sensitive and useful diagnostic tool to detect, monitor, and predict the occurrence of WBD epidemics.

In summary, the present investigation demonstrated that WBD is caused by a novel phytoplasma strain belonging to the 16 SrI group. Based on phylogenetic analysis of the 16S rRNA and rps 19, rpl22, and rps3 gene sequences, the WBD phytoplasma is most closely related to subgroup
16SrI-C phytoplasmas. However, the WBD phytoplasma differs significantly from other phytoplasmas in the $16 \mathrm{SrI}-\mathrm{C}$ subclade because it has a very different host range, and transmission occurs by $P$. striatus leafhopper vectors.

\section{ACKNOWLEDGMENTS}

We thank Professor Yang Ying of Northwest A\&F University for providing paulownia witches'broom (PaWB) phytoplasma-infected plants and Mrs. Nadia Sokal from Agriculture and Agri-Food Canada for editing the manuscript. We thank the two anonymous reviewers and Editor David Coplin for their constructive comments and editing the manuscript. This work was supported by Natural Science Foundation of China (Grant no. 30970133), the 111 Project from Education Ministry of China (Grant no. B07049), and the MOEAAFC Ph.D. Research Program.

\section{LITERATURE CITED}

1. Altschul, S. F., Gish, W., Miller, W., Myers, E. W., and Lipman, D. J. 1990. Basic local alignment search tool. J. Mol. Biol. 215:403410.

2. An, D. R., Wei, N. S., Zhang, Q. F., Zhang, R., and Zhu, X. 1991. The primary report of wheat mycoplasma like-organism blue dwarf disease (WNBD). Acta Phytophylac. Sin. 21:263-266.

3. An, R. S., Tan, S. J., and Chen, X. F. 2002. The improvement of triturating method about DNA extraction of small insect. Insect Knowl. 39:311-312.

4. Batlle, A., Martinez, M. A., and Lavina, A. 2000. Occurrence, distribution and epidemiology of Grapevine Yellows in Spain. Eur. J. Plant Pathol. 106:811-816.

5. Bedendo, I. P., Davis, R. E., and Dally, E. L. 2000. Detection and identification of the maize bushy stunt phytoplasma in corn plants in Brazil using PCR and RFLP. Int. J. Pest Manage. 46:73-76.

6. Bertaccini, A., Franova, J., Botti, S., and Tabanelli, D. 2005. Molecular characterization of phytoplasmas in lilies with fasciation in the Czech Republic. FEMS Microbiol. Lett. 249:79-85.

7. Chiykowski, L. 1967. Reaction of some wheat varieties to aster yellows virus. Can. J. Plant. Sci. 47:149-151.

8. Chiykowski, L. N. 1991. Vector-pathogen-host plant relationships of clover phyllody mycoplasmalike organism and the vector leafhopper Paraphlepsius-Irroratus. Can. J. Plant Pathol.-Rev. Can. Phytopathol. 13:11-18.

9. Firrao, G., Andersen, M., Bertaccini, A., Boudon, E., Bove, J. M., Daire, X., Davis, R. E., Fletcher, J., Garnier, M., Gibb, K. S., Gundersen-Rindal, D. E., Harrison, N. A., Hiruki, C., Kirkpatrick, B. C., Jones, P., Kuske, C. R., Lee, I. M., Liefting, L., Marcone, C., Namba, S., Schneider, B., Sears, B. B., Seemuller, E., Smart, C. D., Streten, C., and Wang, K. 2004. 'Candidatus Phytoplasma', a taxon for the wall-less, non-helical prokaryotes that colonize plant phloem and insects. Int. J. Syst. Evol. Micr. 54(Pt 4):1243-1255.

10. Gundersen, D. E., and Lee, I.-M. 1996. Ultrasensitive detection of phytoplasmas by nestedPCR assays using two universal primer pairs. Phytopathol. Mediterr. 35:144-151.

11. Gundersen, D. E., Lee, I.-M., Rehner, S. A., Davis, R. E., and Kingsbury, D. T. 1994. Phylogeny of mycoplasmalike organisms (phytoplasmas) - A basis for their classification. J. Bacteriol. 176:5244-5254.

12. Harrison, N. A., Richardson, P. A., Tsai, J. H., Ebbert, M. A., and Kramer, J. B. 1996. PCR assay for detection of the phytoplasma associated with maize bushy stunt disease. Plant Dis. 80:263-269.
13. Jomantiene, R., Davis, R. E., Alminaite, A. Valiunas, D., and Jasinskaite, R. 2002. First report of oat as host of a phytoplasma belonging to group $16 \mathrm{SrI}$, subgroup A. Plant Dis. 86:443.

14. Kollar, A., Seemuller, E., Bonnet, F., Saillard, C., and Bove, J. M. 1990. Isolation of the DNA of various plant pathogenic mycoplasmalike organisms from infected plants. Phytopathology 80:233-237.

15. Kuske, C. R., and Kirkpatrick, B. C. 1992 Phylogenetic-relationships between the western aster yellows mycoplasmalike organism and other prokaryotes established by $16 \mathrm{~s}$ ribosomal-RNA gene sequence. Int. J. Syst. Bacteriol. 42:226-233.

16. Lee, I.-M., Davis, R. E., and GundersenRindal, D. E. 2000. Phytoplasma: Phytopathogenic mollicutes. Annu. Rev. Microbiol. 54:221-255.

17. Lee, I.-M., Gundersen-Rindal, D. E., and Bertaccini, A. 1998. Phytoplasma: Ecology and genomic diversity. Phytopathology 88:1359-1366.

18. Lee, I.-M., Gundersen-Rindal, D. E., Davis, R. E., and Bartoszyk, I. M. 1998. Revised classification scheme of phytoplasmas based an RFLP analyses of 16S rRNA and ribosomal protein gene sequences. Int. J. Syst. Bacteriol. 48:1153-1169.

19. Lee, I.-M., Gundersen-Rindal, D. E., Davis, R. E., Bottner, K. D., Marcone, C., and Seemuller, E. 2004. 'Candidatus Phytoplasma asteris', a novel phytoplasma taxon associated with aster yellows and related diseases. Int. J. Syst. Evol. Micr. 54:1037-1048

20. Lee, I.-M., Hammond, R. W., Davis, R. E., and Gundersen, D. E. 1993. Universal amplification and analysis of pathogen 16S rDNA for classification and identification of mycoplasmalike organisms. Phytopathology 83:834-842.

21. Li, Y., Tian, G., ZH, Piao, C. G., and Zhu, S. F. 2005. Rapid molecular differentiation and identification of different phytopla smas from several plants in China. Acta Phytopathol. Sin 35:293-299.

22. Lim, P. O., and Sears, B. B. 1991. DNA sequence of the ribosomal protein genes $\mathrm{rp} 12$ and rps19 from a plant-pathogenic mycoplasma-like organism. FEMS Microbiol Lett. 68:71-73.

23. Lim, P. O., and Sears, B. B. 1992. Evolutionary relationships of a plant-pathogenic mycoplasmalike organism and AcholeplasmaLaidlawii deduced from 2 ribosomal-protein gene-sequences. J. Bacteriol. 174:2606-2611.

24. Liu, S., Liu, J. H., Liu, J. B., Gao, Y. J., and $\mathrm{Wu}, \mathrm{Y}$. 2005. Investigation of infectious conditions of Wheat blue dwarf disease. Shaanxi Agric. Sci. (China) 6:12-13.

25. Madden, T. L., Tatusov, R. L., and Zhang, J. 1996. Applications of network BLAST server. Methods Enzymol. 266:131-141.

26. Marcone, C., Lee, I.-M., Davis, R. E., Ragozzino, A., and Seemuller, E. 2000. Classification of aster yellows-group phytoplasmas based on combined analyses of rRNA and tuf gene sequences. Int. J. Syst. Evol. Micr. 50:17031713.

27. Qinfeng, Z., Rong, Z., Zhiying, R., Yuanli, M. and Zhu, X. 1993. Wheat blue dwarf disease caused by mycoplasma like-organism. Acta Microbiol. Sin. 5:361-364.

28. Qinfeng, Z., and Zhu, X. S. 1994. Wheat MLO disease has been occurred in China. Shaanxi Agric. Sci. (China) (1):17-18.

29. Saitou, N., and Nei, M. 1987. The neighborjoining method - A new method for reconstructing phylogenetic trees. Mol. Biol. Evol 4:406-425.

30. Schneider, B., Gibb, K. S., and Seemuller, E. 1997. Sequence and RFLP analysis of the elongation factor Tu gene used in differentiation and classification of phytoplasmas. $\mathrm{Mi}$ - 
crobiology-Uk 143:3381-3389.

31. Seemuller, E., Schneider, B., Maurer, R., Ahrens, U., Daire, X., Kison, H., Lorenz, K. H., Firrao, G., Avinent, L., Sears, B. B., and Stackebrandt, E. 1994. Phylogenetic Classification of phytopathogenic Mollicutes by sequence-analysis of $16 \mathrm{~s}$ ribosomal DNA. Int. J. Syst. Bacteriol. 44:440-446.

32. Shi, Y. Z., Wu, Y. F., Gu, P. W., An, F. Q., and Yang, Y. 2007 Analysis of the 16S rRNA and elongation factor TU (tuf) gene sequences of Paulownia witches' broom phytoplasma. Chinese J. Microbiol. 34:291-295.

33. Suzuki, S., Oshima, K., Kakizawa, S., Arashida, R., Jung, H. Y., Yamaji, Y., Nishigawa, H., Ugaki, M., and Namba, S. 2006. Interaction between the membrane protein of a pathogen and insect microfilament complex determines insect-vector specificity. Proc. Nat. Acad. Sci. USA 103:4252-4257.

34. Tamura, K., Dudley, J., Nei, M., and Kumar, S. 2007. MEGA4: Molecular evolutionary genetics analysis (MEGA) software version 4.0. Mol. Biol. Evol. 24:1596-1599.
35. Urbanaviciene, L., Jomantiene, R., and Davis, R. E. 2005. First report of barley as host of a phytoplasma belonging to group $16 \mathrm{SrI}$, subgroup B, and ribosomal protein subgroup rpI-B in Lithuania. Plant Dis. 89:339.

36. Urbanaviciene, L., Jomantiene, R., Valiunas, D., and Davis, R. E. 2004. Molecular detection of phytoplasmas in oats, barley, and Triticosecale and their classification based on 16S rRNA gene polymorphisms. Zemes ukio Mokslai (3):15-19.

37. Valiunas, D., Urbanaviciene, L., Jomantiene, R., and Davis, R. E. 2007. Molecular detection, classification and phylogenetic analysis of subgroup 16SrI-C phytoplasmas detected in diseased Poa and Festuca in Lithuania. Biologija 53:36-39.

38. Wei, W., Davis, R. E., Lee, I.-M., and Zhao, Y. 2007. Computer-simulated RFLP analysis of 16S rRNA genes: Identification of ten new phytoplasma groups. Int. J. Syst. Evol. Micr. 57:1855-1867.

39. Xiang, J. Y., Zhang Q. F., and Luo, G. Z. 1994. Characterization of transmission vector Psam- motettix striatus of wheat blue dwarf disease. Shaanxi Agric. Sci. (China) 5:4-5.

40. Xiang, J. Y., Zhu, X. S., and Liu, S. 1996. Studies on bionomics of Psammotettix striatus (L.). Acta Phytophylac. Sin. 23:327-332.

41. Ye, J., McGinnis, S., and Madden, T. L. 2006. BLAST: Improvements for better sequence analysis. Nucleic Acids Res. 34 (Web Server issue):W6-9.

42. Zhang, Q. F., Guan, W. N., Ren, Z. Y., and Zhu, X. S. 1983. Transmission of barley yellow dwarf virus strains from northwestern China by four aphid species. Chinese J. Plant Dis. 67:895-899.

43. Zhang, Q. F., Xiang, J. Y., Yang, Y., and Zhang, R. 1996. The primary infection of wheat mycoplasmalike organism blue dwarf disease (WMBD). Acta Phytophylac. Sin. 11:107-110.

44. Zhu, X., and Zhang, S. L. 1984. Investigation of wheat blue dwarf disease. Acta Phytophylac. Sin. 11:35-41.

45. Zhu, X., Zhang S. L. 1984. Investigation of wheat blue dwarf disease. Acta Phytophylac. Sin. 11:35-41. 